\title{
WALORY KRAJOZNAWCZE XXI FESTIWALU SŁOWIAN I WIKINGÓW NA WOLINIE ${ }^{1}$
}

\begin{abstract}
Abstrakt: Artykuł omawia wpływ walorów krajoznawczych na postrzeganie XXI edycji Festiwalu Słowian i Wikingów jako wydarzenia atrakcyjnego turystycznie. Przybliża także zarys aktywności, jaką jest rekonstrukcja historyczna/odtwórstwo historyczne. Prezentowane w nim są wyniki badań ankietowych przeprowadzonych w trakcie wydarzenia wśród odwiedzających oraz uczestników-rekonstruktorów mające za zadanie uwiarygodnienie tezy o wysokiej atrakcyjności turystycznej Festiwalu.

Słowa kluczowe: rekonstrukcja historyczna, atrakcyjność turystyczna, walor, festiwal.
\end{abstract}

\section{THE TOURIST ASSETS OF THE $21^{\text {ST }}$ FESTIVAL OF SLAVS AND VIKINGS ON WOLIN ISLAND}

Abstract: The article discusses influence of sightseeing values of XXI edition of Festival of Slavs and Vikings as touristically attractive event. It also brings closer the outline of activity of historical reenactment. The results of surveys performed during the Festival among tourists and reenactors and presented in the text are aimed to confirm the thesis about high attractiveness of the event. This text is based on a Bachelor thesis titled Tourism attractiveness of the XXI Festival of Slavs and Vikings written with the help of Dr Joanna Latosinska.

Keywords: historical reenactment, tourism attractiveness, value, festival.

\section{WSTĘP}

W obliczu odradzającej się w społeczeństwie potrzeby poznawania własnych korzeni, coraz intensywniej rozwija się moda na ożywianie dawnych dziejów dzięki rozmaitym wydarzeniom poświęconym historii. Ta dziedzina wiedzy, wychodząc poza muzea $i$ instytuty archeologii oraz przybierając formę festiwali historycznych, staje się stałym elementem turystyki, wypełniając jej kolejną niszę. W trend ten wpisuje się Festiwal Słowian i Wikingów na Wolinie. Jego XXI edycja, która odbywała się między 31 lipca a 2 sierpnia 2015 r., przyciągnęła ponad 2000 rekonstruktorów oraz ponad 30000 odwiedzających z różnych krajów świata. Takie statystyki stanowią o tym, że rekonstrukcja historyczna od jakiegoś już czasu obserwowana jest przez badaczy turystyki, którzy szukają odpowiedzi na pytanie, jakie walory turystyczne świadczą o tworzeniu atrakcyjności turystycznej tego rodzaju wydarzeń (PAWLETA 2012).

Celem autora niniejszego artykułu jest analiza fenomenu Festiwalu Słowian i Wikingów, ocena najważniejszych z elementów atrakcyjności turystycznej jego XXI edycji, a także prezentacja Festiwalu oraz odtwórstwa i rekonstrukcji historycznej w kontekście turystyki.

\section{RUCH ODTWÓRSTWA WCZESNEGO ŚREDNIOWIECZA}

Fascynacja przeszłością od dawna miała swoje odbicie na różnych płaszczyznach życia całych społeczeństw, a także i człowieka jako jednostki. Odtwarzanie i rekonstruowanie wydarzeń, postaci oraz artefaktów z minionych czasów to najwyraźniejszy i najbardziej namacalny objaw owego zainteresowania. Od starożytności do czasów nowoczesnych ten rodzaj aktywności przyjmował różne formy, lecz dopiero koniec XX w. ukształtował zjawisko, które nazywane jest rekonstrukcją historyczną lub odtwórstwem historycznym.

Jest to jedna $\mathrm{z}$ form przybliżania historii, a konkretniej - wprowadzania jej w życie. Są to liczne działania, w trakcie których ich uczestnicy, czyli rekonstruktorzy, odtwarzają realia i ducha wybranej epoki. Rekonstrukcja wymaga oparcia na gotowych opracowaniach naukowych lub też samodzielnego zgłębiania źródeł historycznych i materialnych pozostałości danego okresu. Ma to na celu jak najwierniejsze oddanie rzeczywistości minionego czasu. Rekonstrukcja historyczna obejmuje czynności związane z życiem codziennym, rzemiosłem, sztuką, militariami, a nawet obrzędami religijnymi (BOGACKI 2010). 
Współcześnie rekonstrukcja wczesnego średniowiecza ulega profesjonalizacji w stosunku do jej wyglądu sprzed dekady i czasów jeszcze bardziej odległych. Powstają coraz nowsze grupy, których wyposażenie stoi na wysokim poziomie odtwórczym, starsze grupy wymieniają swój sprzęt na bardziej historyczny. Wynika to m.in. ze współpracy wspomnianych drużyn z ośrodkami naukowymi, jak np. instytuty archeologiczne państwowych uczelni, spośród których często rekrutują się rekonstruktorzy. Wpływ na polepszenie jakościowe tego zjawiska ma również dużo łatwiejszy dostęp do Internetu stanowiącego przestrzeń wymiany wiedzy i doświadczenia w różnej formie - ikonografii, na której można bazować w tworzeniu sylwetki historycznej, zdjęć znalezisk archeologicznych, tekstów źródeł pisanych lub wykrojów ubioru. Coraz powszechniejszym zjawiskiem jest komercjalizacja odtwórstwa. Rzemieślnicy, którzy kiedyś tworzyli na małą skalę, teraz produkują towary, takie jak: uzbrojenie, stroje, artykuły średniowiecznego gospodarstwa domowego dla szerokiego grona odbiorców, a ich działalność w rekonstrukcji historycznej przyjmuje funkcję głównie zarobkową (GÓREWICZ 2013).

Część drużyn rejestruje się obecnie jako stowarzyszenia, a kolejny ułamek zakłada działalność gospodarczą skierowaną na odpłatne organizowanie pokazów przy różnych okazjach. Chcąc przyporządkować rekonstrukcję historyczną którejś z dziedzin turystyki, należy odwołać się do definicji turystyki kulturowej. Według A. KOWALCZYKA (2008, s. 14) turystyka kulturowa jest to „zespół zachowań turystów związanych $\mathrm{z}$ ich zainteresowaniem kultura, czyli zabytkami, folklorem, miejscami związanymi $\mathrm{z}$ ważnymi wydarzeniami”. Turystyka kulturowa obejmuje także „uczestnictwo turystów w szeroko rozumianym życiu kulturalnym”. Według definicji W. KOPALIŃSKIEGO (2003, s. 169-170) festiwal to „okresowa uroczystość, złożona z imprez (często także konkursów) artystycznych oraz spotkań, umożliwiających przybyłym z różnych stron uczestnikom nawiązanie kontaktów kulturalnych (niekiedy i politycznych)".

Festiwal Słowian i Wikingów na Wolinie oficjalnie stanowi pierwsze wydarzenie poświęcone realizacji odtwarzania wczesnego średniowiecza w Polsce. Jego pierwsza edycja odbyła się w roku 1993 a co więcej, rok $\mathrm{w}$ rok jest największym tego typu wydarzeniem na świecie (GóREWICZ 2013). Na Festiwalu tym można spotkać zarówno drużyny młode, jak i bardziej doświadczone. Natrafić można tam na osoby o dobrze skrojonej sylwetce historycznej, ze spójnym kontekstem znalezisk, na których opiera swój wygląd, jak i osoby nieposiadające podstawowych elementów wyposażenia, jednocześnie obleczone $\mathrm{w}$ zbyt bogate ozdoby. Taka mieszanka sprawia, że Festiwal na Wolinie jest niejednokrotnie celem zarzutów o zbytnią komercję i masowość. Z drugiej jednak strony sympatycy Festiwalu wiedzą dobrze, że nie jest to problem jedynie imprezy na Wolinie, ale generalnie wielu drużyn czy wydarzeń, a sam Festiwal Słowian i Wikingów stanowi pewien fundament, na którym wyrosła polska rekonstrukcja wczesnego średniowiecza, ale również i zagraniczna.

\section{WALORY KRAJOZNAWCZE}

Walory turystyczne, według T. LIJEWSKIEGO, B. MIKUŁOWSKIEGO i J. WYRZYKOWSKIEGO (2008, s. 14), „stanowią specyficzne cechy i elementy środowiska naturalnego oraz przejawy działalności człowieka, które są przedmiotem zainteresowań turystów". Wśród tych walorów, zgodnie $\mathrm{z}$ podziałem dokonanym przez autorów przytoczonej definicji, znajdują się walory wypoczynkowe, specjalistyczne oraz walory krajoznawcze. Festiwal Słowian i Wikingów posiada cechy, które budują jego atrakcyjność głównie w oparciu o walory krajoznawcze, które z kolei dzielą się na walory przyrodnicze oraz antropogeniczne, na których warto się skupić.

\subsection{KRAJOZNAWCZE WALORY PRZYRODNICZE}

Definiując walor przyrodniczy T. LIJEWSKI, B. MIKUŁOWSKI i J. WYRZYKOWSKI (2008, s. 14-15) posłużyli się słowami O. ROGALEWSKIEGO (1979) opisującymi go jako charakterystyczny zespół krajobrazowy i osobliwość przyrody. Jest to wyjaśnienie adekwatne do otoczenia naturalnego obszaru, na którym odbywa się Festiwal.

Określając wpływ walorów przyrodniczych na atrakcyjność turystyczną, należy zacząć od ogółu, skupiając się następnie na szczególach. Dlatego też ważne jest, by scharakteryzować krótko główne cechy przyrody Pomorza Zachodniego oraz wyspy Wolin. Następnie $\mathrm{w}$ ich kontekście trzeba umieścić samo miejsce odbycia się XXI Festiwalu Słowian i Wikingów, czyli Wolińską Kępę nazywaną inaczej Ostrowem.

Pomorze Zachodnie jest krainą historyczno-geograficzną w północno-zachodniej części Polski, lecz jego część należy też do Niemiec - granica między tymi krajami przebiega wzdłuż dolnej Odry, następnie ku północy poprzez Zalew Szczeciński oraz wyspę Uznam. Tych kilka wspomnianych elementów przyrody oraz Morze Bałtyckie i wyspa Wolin pozwala opisać środowisko przyrodnicze Pomorza Zachodniego jako obszar nadmorski, nadrzeczny, leżący nad zalewem i obejmujący niewielkie wyspy (LIJEWSKI, MIKUŁOWSKI , WYRZYKOWSKI 2008).

$\mathrm{W}$ regionie Pomorza Zachodniego zawiera się wyspa Wolin. Warunki naturalne, jak na 265 km² 
powierzchni, są na niej dość zróżnicowane. Występują tu: najwyższe w Polsce wybrzeże klifowe o wysokości do $80 \mathrm{~m}$ i długości $15 \mathrm{~km}$ wzdłuż linii wybrzeża, pasmo wzniesień morenowych $\mathrm{z}$ kulminacją wysoka na 116 m n.p.m., nazywaną Grzywaczem, polodowcowe Pojezierze Wolińskie ze zbiornikami będącymi w większości kryptodepresją oraz trzy półwyspy - Przytorski, Międzywodzki i Rów. Szczególnym krajoznawczym walorem przyrodniczym jest Woliński Park Narodowy, który chroni gatunki rzadkie, w tym spośród fauny orła bielika, żubra, fokę szarą czy morświna, a spośród flory honkenię piaskową, rukwiel nadmorską oraz około 30 gatunków halofitów. W ramach parku wyznaczonych jest sześć rezerwatów ścisłych, ale także dziewięć szlaków turystycznych, a wśród nich szlaki piesze, rowerowe i ścieżki przyrodnicze.

Granice wyspy Wolin od północy wyznacza Morze Bałtyckie. Na zachodzie, oddzielając Wolin od Uznamu, płynie Świna. Od południa Wolin otacza Zalew Szczeciński, na wschodzie natomiast Zalew Kamieński oraz cieśnina Dziwna, na której znajduje się Wolińska Kępa, czyli miejsce, gdzie zorganizowany został XXI Festiwal Słowian i Wikingów (http:/ / www.wolinpn.pl).

Sama Wolińska Kępa, będąca ścisłym otoczeniem przyrodniczym XXI Festiwalu Słowian i Wikingów, jest $\mathrm{w}$ pewnym stopniu poddana modyfikacjom ze strony człowieka. Abstrahując od Skansenu Słowian i Wikingów, Ostrów przecinają drogi oraz most. Tereny wokół Skansenu wymagały osuszenia w celu zabezpieczenia obiektu i umożliwienia jego rozbudowy, co też uczyniono.

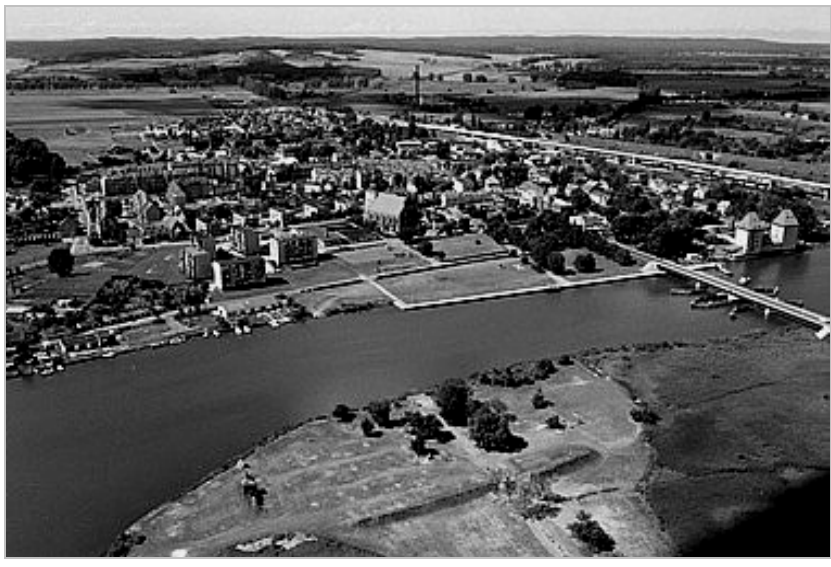

Fot. 1. Zachodni brzeg Wolińskiej Kępy przed powstaniem Skansenu Słowian i Wikingóworaz zabudowa Wolina Źródło: digitalphoto.pl

Ostrów cechuje się bardzo niskim zalesieniem - rośnie tam zaledwie kilkanaście drzew, z czego większość to gatunki liściaste. Bogaty jest natomiast $\mathrm{w}$ trawy oraz rośliny nadwodne, takie jak trzciny i tataraki. Wyb- rzeża wyspy pokryte są trawą wymieszaną niekiedy $z$ piaskiem oraz kamieniami. $W$ cieśninie, mylonej czasami z rzeką, płynie woda słodka $z$ dużym wpływem słonej, a ciekawostką jest fakt, że Dziwna może zmieniać kierunek swojego prądu - stąd też, według miejscowej ludności, wzięła się jej nazwa. Dno ma charakter mułowo-piaskowy.

\subsection{KRAJOZNAWCZE WALORY ANTROPOGENICZNE}

Festiwal, jak zostało udowodnione we wstępie do niniejszej pracy, stanowi sumę pewnych walorów mających swe źródło w działaniach człowieka kierowanych w stronę innego człowieka. Walory antropogeniczne odgrywają dużą rolę $\mathrm{w}$ ocenie atrakcyjności turystycznej XXI Festiwalu Słowian i Wikingów.

Podobnie jak w przypadku charakterystyki elementów naturalnych, otoczenie antropogeniczne Festiwalu należy umieścić w nieco szerszym kontekście. Jak wykazały badania autora (zarówno obserwacja, jak i ankiety) wykonane w trakcie jego XXI edycji, uczestnicy oraz odwiedzający bardzo często podążają poza główny tor wydarzenia, by zwiedzić lub zobaczyć inne lokalne atrakcje Wolina. Rys. 1 prezentuje 17 zabytków i atrakcji nawiązujących do historii miasta Wolin, od wczesnego średniowiecza aż do wieku XIX. Wyraźnie zaznaczona została Wolińska Kępa, na której znajduje się Skansen Słowian i Wikingów, będący jednocześnie najbliższym otoczeniem antropogenicznym omawianego wydarzenia.

Skansen został otwarty w 2008 r. i ciągle jest rozbudowywany o kolejne chaty, elementy obronne, takie jak palisady, wieże i bramy oraz inne wzorowane na historycznych artefaktach elementy przestrzeni. W czasie XXI Festiwalu Słowian i Wikingów obecnych było 25 rekonstrukcji historycznych domów (z 27 przewidzianych $\mathrm{w}$ projekcie) o pięciu typach konstrukcji: zrębowej, plecionkowej, palisadowej, międzysłupowej oraz sumikowo-łątkowej. Ponadto cztery wiaty rzemieślnicze, nabrzeże portowe, półotwarty chram, dwie bramy ( $z$ czterech planowanych na następne lata) połączone palisadą oraz sauna słowiańska, tzw. bania. Budynkom o charakterze historycznym towarzyszy poboczna infrastruktura w postaci kuchni, zaplecza biurowego, budynku $\mathrm{z}$ dostępem do toalety i pryszniców oraz parking. Jest to o tyle istotne, że w przestrzeni tej osadzony został najważniejszy walor antropogeniczny XXI Festiwalu Słowian i Wikingów - jego program, czyli zestaw atrakcji przygotowanych dla rekonstruktorów oraz odwiedzających (http:// www.jomsborg-vineta.com). Program został podzielony na pięć grup: fizyczną, rzemieślniczo-obozową, rozrywkową, literacko - naukową oraz obrzędową. 


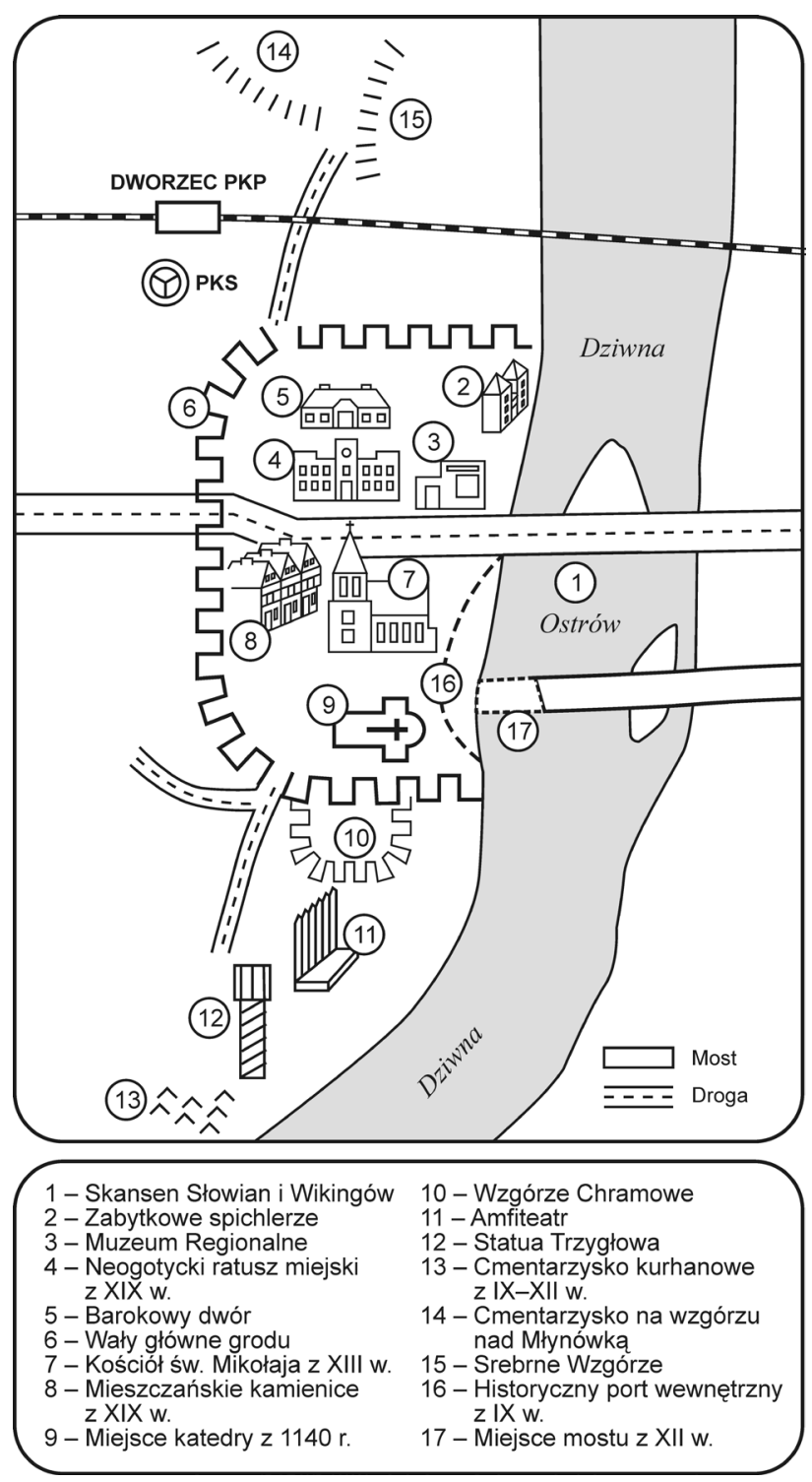

Rys. 1. Uproszczone rozmieszczenie atrakcji miasta Woli Źródło: opracowanie własne na podstawie W. MECHŁO (2010, s. 198-199)

Zdecydowanie najbardziej znaczącym zainteresowaniem, co wykazały również badania ankietowe, cieszyła się pierwsza grupa - prawdopodobnie ze względu na największą spektakularność. Dział ten obejmuje atrakcje związane $\mathrm{z}$ walką, rywalizacją fizyczną, aspektem militarnym życia, swego rodzaju sportem, gdyż jak wiadomo, bitwy lub pojedynki rekonstruktorskie nie mają na celu rzeczywistej likwidacji rywala, lecz ukazanie prawdopodobnego ich obrazu, jaki mogły przybierać we wczesnym średniowieczu.

Wśród atrakcji tej grupy znajdują się:

- bitwa około 500 wojów podzielonych na dwie armie, toczona niezależnie od pogody, składająca się z trzech starć; odbywała się każdego dnia i stanowiła główny cel odwiedzin Festiwalu wielu odwiedzających, ale też odtwórców, dla których walka w prawdopodobnie największej bitwie wśród wczesnośredniowiecznych imprez jest nie lada przeżyciem; autor, na zaproszenie organizatorów wydarzenia, również wziął w tym punkcie programu udzial;

- walka o most, czyli seria potyczek 5-osobowych drużyn odpadających po przegranej;

- turniej indywidualny, w którym wyznaczeni przez swoje drużyny wojownicy toczyli pojedynki mające wyłonić najlepszego woja Festiwalu, a zwycięzca został nagrodzony mieczem;

- bitwa morska, będąca rzeczywiście inscenizacją walki pomiędzy załogami kilku replik historycznych łodzi; widzowie mogli podziwiać zarówno sprawność wojowników, jak również kunszt żeglarski kapitanów okrętów;

- turniej łuczniczy, wyłaniający najlepszego wśród uczestników Festiwalu strzelca;

- wikiński test wody, będący serią walk na kije na desce umieszczonej między dwiema łodziami, w której wygrywa ten woj, któremu uda się nie wpaść do wody;

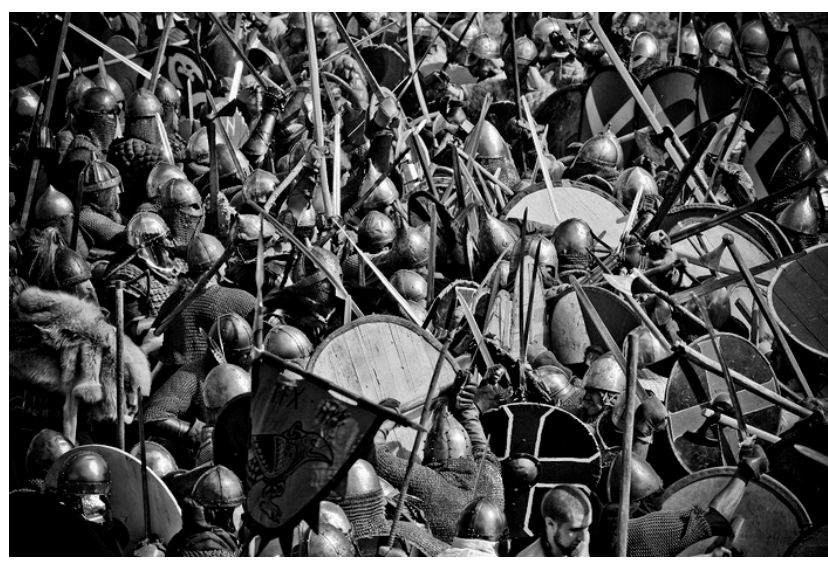

Fot. 2. Rekonstrukcja bitwy wczesnośredniowiecznych wojów podczas festiwalu Słowian i Wikingów na Wolinie Źródło: http://www.wsieciprawdy.pl

Do grupy atrakcji rzemieślniczych oraz obozowych należą wszelkie produkty rękodzielnicze wystawiane na kramach, uprzednio wykonane przez rzemieślników lub wyrabiane na żywo, na oczach odwiedzających. Należy zaliczyć tu również życie obozowe, mające przybliżyć podstawowe aspekty życia codziennego ludzi żyjących we wczesnym średniowieczu, takie jak praca, posiłek, odpoczynek oraz elementy wyposażenia namiotów czy chat - zarówno użytkowe, jak i ozdobne. Na kramach rzemieślników i handlarzy można było zobaczyć produkty z drewna, kości, odlewane $z$ brązu, wykuwane ze stali, wypalane $z$ gliny, ale też wyroby tkane $z$ lnu lub wełny, szyte ze skóry. Odwiedzający oraz odtwórcy mogli zakupić większość z tych przedmiotów, a u niektórych kramarzy 
możliwe było podjęcie się samodzielnego wykonania wybranych przedmiotów. Atrakcje rzemieślnicze stanowią poniekąd aspekt komercyjny Festiwalu, gdyż wielu z wystawców za cel przyjazdu obiera zarobek ze sprzedaży i promocji swych dzieł.

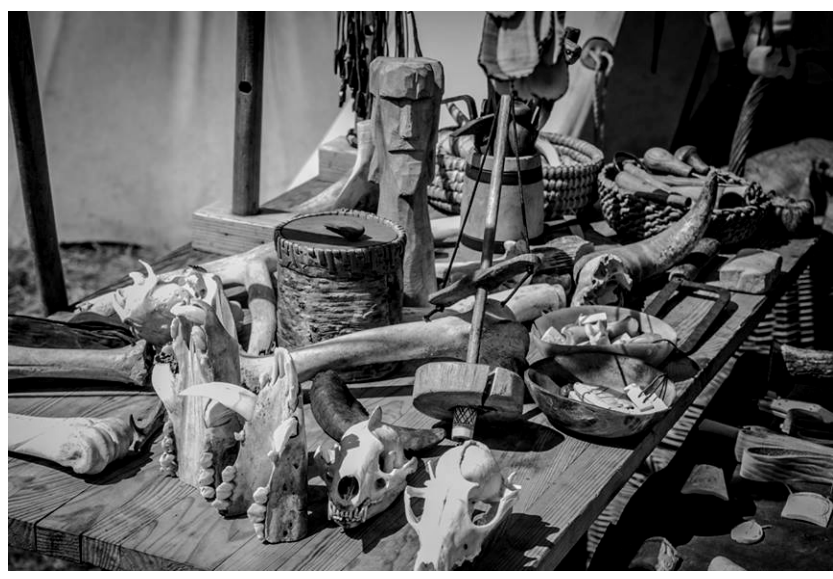

Fot. 3. Wytwory replik rzemiosła wczesnośredniowiecznego na Wolinie

Źródło: materiały autora

Trzecia grupa atrakcji, określona mianem rozrywkowej, obejmuje wszelkie konkursy, prezentacje historycznych zabaw i gier oraz występy artystyczne. Duża część tego zbioru stanowiły przedstawienia obsadzone w realiach historycznych, a wśród nich:

- „Beowulf” oraz „Holmgang” w wykonaniu Drużyny Krak;

- „Dola wojownika” będąca cyklem inscenizacji organizowanych przez różne grupy;

- „Harald Srogi na Rusi” w aranżacji Drużyny Grodu Horodna;

- „Olaf Tryggvason na Wolinie”, czyli przedstawienie, w którym udział wzięły dzieci z Wolina.

Szwedzka grupa Birka Boys uczyła chętnych odwiedzających oraz innych rekonstruktorów, jak grać i bawić się przy użyciu kijów, lin, pni drzew i własnego ciała, a Drużyna Krak prezentowała grę w średniowiecznego palanta.

Sporym zainteresowaniem cieszyły się również targi niewolników i niewolnic, na których za wylicytowaną cenę odwiedzający mogli kupić wystawianych odtwórców, a następnie użyć ich według własnej woli. Organizatorzy postarali się również o konkursy, które są jednym $z$ elementów niezbędnych festiwalu według przytoczonej we wstępie niniejszej pracy definicji. Zarówno rekonstruktorzy, jak i odwiedzający mogli wziąć udział w konkursie na najdostojniejszą brodę wikińską oraz warkocz kobiecy, na najsmaczniejsze jadło wczesnośredniowieczne, a część jury składała się także z osób spoza rekonstrukcji historycznej. Miały miejsce również wybory najpiękniejszego stroju kobiecego, lecz uczestniczyć w nim mogły tylko rekons- truktorki. Nie zabrakło atrakcji dla fanów muzyki oraz tańca. Na Festiwal przybyli bardowie z Polski w zespołach, takich jak Ęzibaba, Percival oraz Gędźba, ale także zza granicy - pośród nich białoruskie Stary Olsa i Lutaś oraz Kalabalik ze Szwecji. Podczas występów muzycznych chętni mogli nauczyć się tańczyć tak jak to niegdyś bywało.

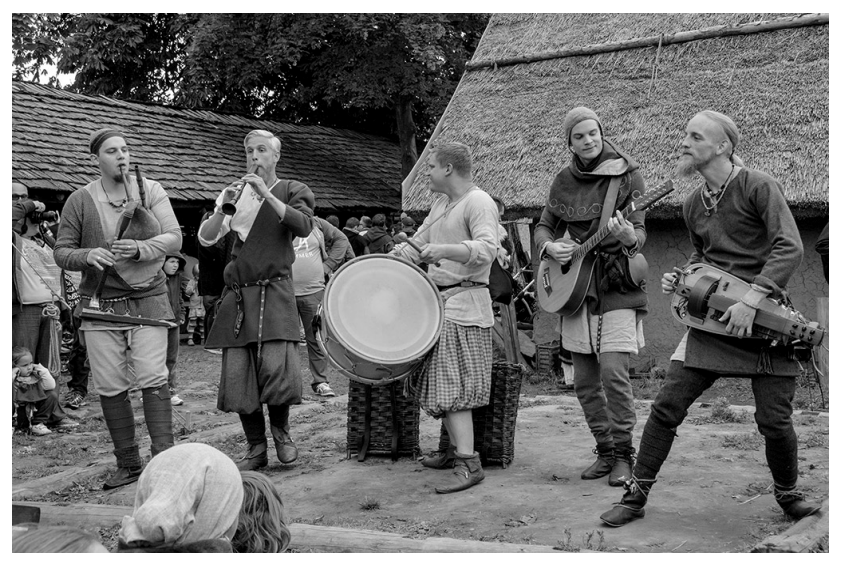

Fot. 4. Występ zespołu Kalabalik ze Szwecji podczas Festiwalu Słowian i Wikingów na Wolinie Zródło: materiały autora

Część literacko-naukowa Festiwalu okazała się podczas jego XXI edycji również stosunkowo bogata. Odbyło się dziewięć prelekcji w strefie przygotowanej na realizację tego punktu programu prezentujących takie tematy, jak:

a) „Wszystkie żony Ragnara Lodbroka” według Łukasza Malinowskiego;

b) „Kobiety Olafa Świętego” - prelekcja Aleksandry Jochymek;

c) „Królowa Geira z Wendlandii - żona Olafa Tryggvasona?" - prelekcja Grzegorza Bartusika;

d) "Apolonia Załuska-Strömberg - współczesna Słowianka w Skandynawii" - wykład Jakuba Morawca;

e) „Historia walk o Arkonę" - opowieść Pawła Babija;

f) „Rekonstrukcja niemożliwego, czyli o odtwarzaniu wczesnośredniowiecznej walki mieczem i tarczą w kontekście źródeł z epoki" - przygotowana przez Pawła Adamca;

g) „Szklana biżuteria wczesnośredniowieczna” - prezentacja Marty Krzyżanowskiej i Mateusza Frankiewicza;

h) „Północny mariaż Ryksy, córki Bolesława Krzywoustego" według Remigiusza Gogosza;

i) „Omówienie podstawowych różnic pomiędzy mieczami używanymi we współczesnych rekonstrukcjach historycznych a oryginalnymi mieczami z epoki na wybranych przykładach" - przez Macieja Kopciucha. 
Ponadto miały miejsce spotkania $\mathrm{z}$ autorami powieści historycznych oraz książek inspirowanych historią naszego oraz skandynawskiego kregu kulturowego. Do dyspozycji uczestników Festiwalu i odwiedzających byli następujący pisarze:

- Władysław Grabski, autor Sagi o Jarlu Broniszu, Łukasz Malinowski, autor Skalda oraz Magdalena Zawadzka-Sołtysek, autorka Gry bogów; poprowadzili oni „Spotkanie z powieścią historyczną";

- Aleksandra Jochymek, Remigiusz Gogosz, Jakub Morawiec, Łukasz Neubauer, czyli autorzy książki Sagi islandzkie. Zarys dziejów literatury staroskandynawskiej, o której mówili w trakcie sesji "Czym były sagi islandzkie i jak je czytać";

- Hanna i Paweł Lisowie, autorzy książki Kuchnia Stowian, czyli o poszukiwaniu dawnych smaków;

Elżbieta Żukowska i Zbigniew Larwa, czyli scenarzystka i rysownik, którzy obecnie pracują nad komiksem Obodrzyce w planszach $i$ kadrach.

Bardzo szczególnym momentem drugiego dnia Festiwalu była udana próba ustanowienia rekordu świata $\mathrm{w}$ jednoczesnym zbiorowym recytowaniu wersów Eddy poetyckiej, będącej jednym z najwspanialszych zabytków nie tylko literatury średniowiecznej Skandynawii, ale i Europy.

Ostatnia grupa atrakcji programu XXI Festiwalu Słowian i Wikingów, czyli część obrzędowa, koncentrowała się wokół chramu Świętowita, znajdującego się $\mathrm{w}$ centrum zabudowy skansenu. Za ten duchowy aspekt odpowiadała grupa Kolovrat z Kalisza, składająca się z osób rzeczywiście wyznających rodzimowierstwo słowiańskie.

Festiwal rozpoczął się wielkim korowodem wszystkich drużyn biorących udział w wydarzeniu. Ruszył spod katedry w Wolinie, po zachodniej stronie Dziwnej, i maszerował aż do wspomnianego chramu w skansenie, gdzie oficjalnie zainaugurowano imprezę, rozpalając ogień specjalnie do tego przygotowanym świdrem. Drugi dzień Festiwalu również przyniósł zdarzenie będące ważnym $\mathrm{z}$ punktu widzenia dawnej wiary - była nim Swaćba, czyli obrzęd zaślubin chętnej pary (która oczywiście się znalazła) przed obliczem Świętowita i przy udziale żercy, czyli kapłana z drużyny Kolovrat.

W ostatni dzień Festiwalu miało miejsce ofiarowanie $w$ intencji udanych żniw i obfitego plonu. Ponadto w wyznaczonych godzinach każdego dnia świątynia była otwarta dla zwiedzających, a obecny tam żerca przygotowywał wróżby, składał ofiary, a dzieciom rekonstruktorów-rodzimowierców nadawał imię w trakcie postrzyżyn.

Momentem religijnym rozpoczynającym bitwę, wyjątkowo odbywającym się poza świątynią, była wróżba dotycząca wyniku bitwy, w której prowa- dzony przez kapłana koń przechodził przez położone na ziemi włócznie, a gdy żadnej nie dotknął, miało to świadczyć o pomyślnym przebiegu walki. Obrzęd ten wzorowany był na opisach znanych średniowiecznych kronikarzy: Thietmara, Herborda oraz Saksona Gramatyka.

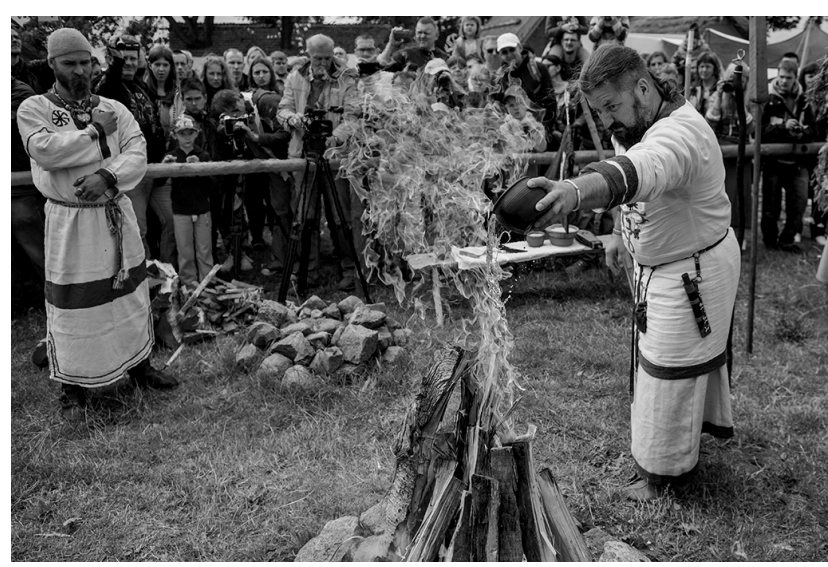

Fot. 5. Obrzęd składania ofiary w intencji bogatych plonów podczas Festiwalu Słowian i Wikingów na Wolinie Źródło: materiały autora

Dosyć istotną cechą programu XXI Festiwalu Słowian i Wikingów na Wolinie była realizacja poszczególnych jego punktów niejednokrotnie w różnych miejscach skansenu, ale o jednym czasie. Takie rozwiązanie sprawia, że odwiedzający oraz uczestnicyodtwórcy czuli pewien niedosyt, co skłaniało ich do wzięcia udziału w kolejnym dniu wydarzenia, kiedy część atrakcji była powtarzana (jak np. przedstawienia teatrzyku historycznego lub występy zespołów muzycznych), a być może nawet w następnej jego edycji.

W przypadku Festiwalu Słowian i Wikingów walory turystyczne mają większościowy udział w ocenie atrakcyjności turystycznej wydarzenia - ich znaczenie jest silniejsze niż rola zagospodarowania turystycznego lub dostępności komunikacyjnej, co potwierdzają wyniki badań ankietowych.

\section{OCENA FESTIWALU W ŚWIETLE BADAŃ ANKIETOWYCH}

Analiza ocen odtwórców oraz odwiedzających biorących udział w XXI Festiwalu Słowian i Wikingów pozwala dokonać weryfikacji tezy o jego wysokiej atrakcyjności turystycznej. Dwie wersje kwestionariusza ankiety dają szansę nakreślenia różnic $\mathrm{w}$ postrzeganiu wydarzenia przez osoby tworzące Festiwal i będące dla gości jego tłem, oraz przez odwiedzających. Wśród rekonstruktorów zostało przeprowadzonych 87 ankiet, z kolei odwiedzający wypełnili 33 kwestionariusze. 
Pierwsze pytanie dotyczyło liczby odwiedzonych przez ankietowanego edycji Festiwalu. W przypadku uczestników odpowiedzi w 87 ankietach wahały się od 1 aż do 20 edycji, a średnia liczba "zaliczonych" Festiwali wynosiła 4,95. Respondenci odwiedzający pojawiali się na Festiwalu od 1 do 16 razy, tworząc średni wynik 2,7 edycji dla 33 wypełnionych kwestionariuszy.

Kolejne pytanie pozwoliło sprawdzić, co w Festiwalu Słowian i Wikingów jest zachęcającego do wzięcia w nim udziału, a biorąc pod uwagę odpowiedzi na pytanie $\mathrm{nr} 1$, co również wielu z uczestników i odwiedzających przyciąga na wydarzenie po raz kolejny. Jak wynika z przeprowadzonych badań czynnikiem tym jest najczęściej chęć doświadczenia atmosfery Festiwalu (rys. 2).

Obserwacja uczestników i odwiedzających pozwoliła zdefiniować ową atmosferę. Według nich jest to możliwość spotkania się ze starymi znajomymi, szansa poznania nowych, udział we wspólnej zabawie, towarzystwo turystów dla rekonstruktorów i obecność odtwórców według odwiedzających. Wśród uczestników dość częstą odpowiedzią było współtworzenie jednego z punktów programu imprezy. Co ciekawe, odpowiedzi tej udzielali najczęściej mężczyźni, którzy mieli zapewne na myśli udział w walce w czasie bitwy lub podczas potyczek. Odwiedzający nie mogli w swojej wersji kwestionariusza zaznaczyć tej odpowiedzi z oczywistych względów.

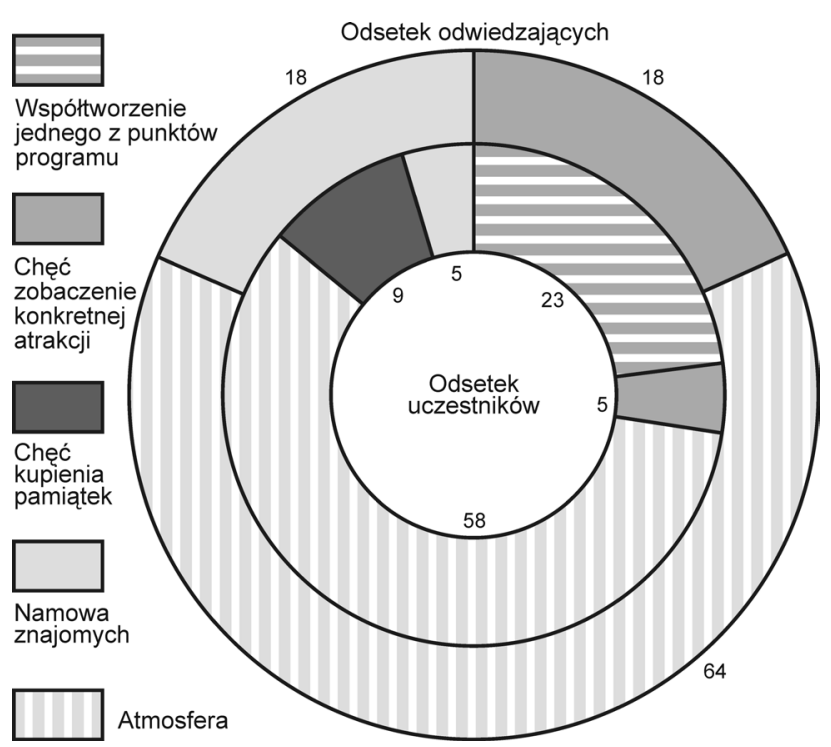

Rys. 2. Główny powód przyjazdu na Festiwal Słowian i Wikingów na Wolinie

Źródło rys. 2-7: opracowanie własne na podstawie badań ankietowych

Dużą różnorodność odpowiedzi wykazała analiza pytania dotyczącego liczby spędzonych lub planowanych dni uczestnictwa. Znakomita większość rekon- struktorów (95\%) deklarowała udział we wszystkich trzech dniach wydarzenia, natomiast wśród odwiedzających najpopularniejszym wariantem zwiedzania była wizyta jednodniowa (63\%) (rys. 3). Wynika to prawdopodobnie ze stopnia udziału obu grup w tworzeniu Festiwalu; uczestnicy są jego nieodłącznym elementem, natomiast turyści i wycieczkowicze są jedynie obserwatorami.

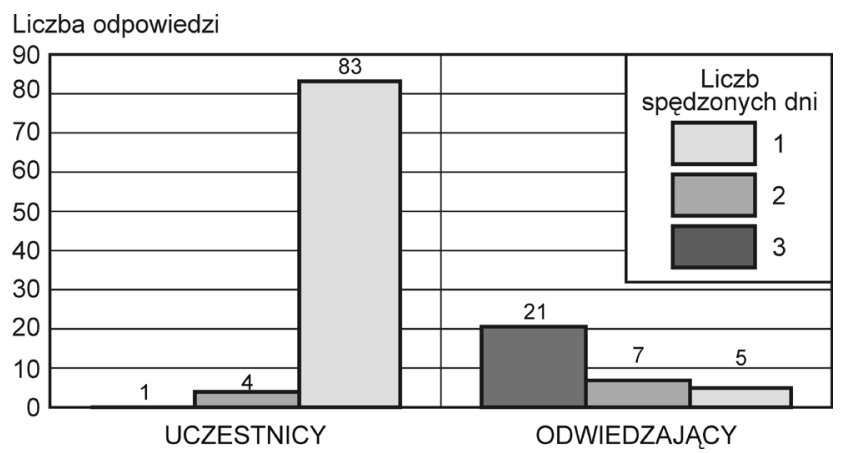

Rys. 3. Liczba spędzonych dni na Festiwalu Słowian i Wikingów na Wolinie

Dość interesujące okazały się średnie oceny przyznawane przez ankietowanych za poszczególne elementy świadczące o jakości wydarzenia (rys. 4). Żaden $z$ aspektów Festiwalu nie został średnio oceniony na notę niższą niż 3, lecz każdy z nich uzyskał nieco więcej punktów $\mathrm{u}$ odwiedzających aniżeli u uczestników. Fakt ten można uzasadnić dużo krótszym czasem przebywania $\mathrm{w}$ jednym miejscu przez pierwszą wymienioną grupę niż przez rekonstruktorów, zatem dużo częściej uczestnicy wynajdują rozmaite niedociągnięcia ze strony organizatorów.

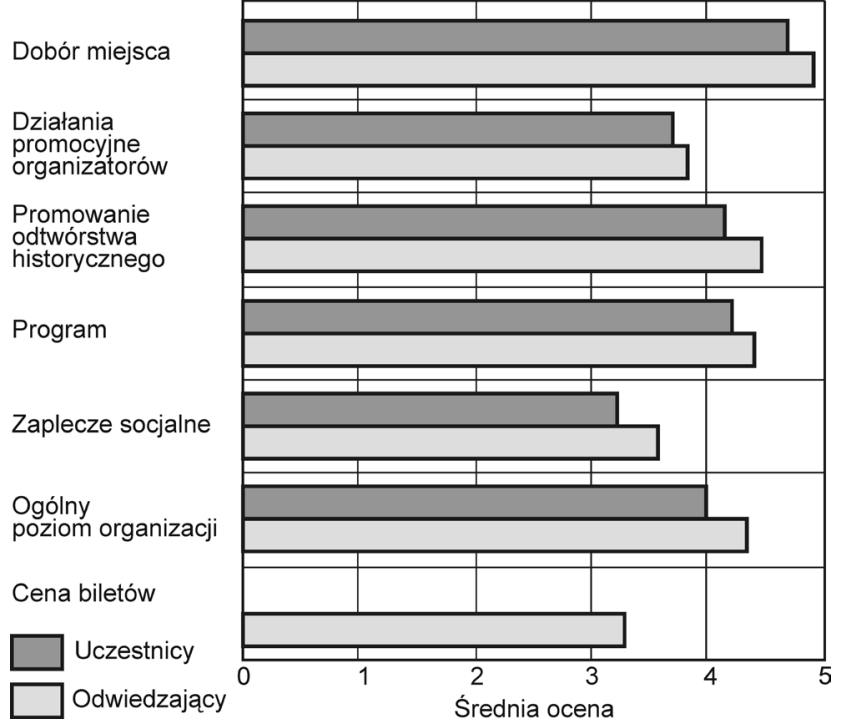

Rys. 4. Średnia ocena poszczególnych elementów Festiwalu Słowian i Wikingów na Wolinie 
Pytanie o poczucie bezpieczeństwa na Festiwalu pozostawia małe tylko wątpliwości - $100 \%$ odwiedzających zadeklarowało pełen komfort w tym aspekcie, natomiast jedynie trzy osoby spośród 87 uczestników wyraziły pewne obawy $\mathrm{z}$ różnych względów. Jedna zauważyła niedostateczne zabezpieczenie medyczne wydarzenia, jednak najpewniej kierowała się chwilowym tylko niepokojem zaznaczając tę odpowiedź.

Atmosfera Festiwalu w znacznej mierze przyczyniała się do głębszego zainteresowania historią i ruchem odtwórstwa historycznego, o czym mówią deklaracje zarówno uczestników, jak i odwiedzających. 83 rekonstruktorów oraz 29 turystów i wycieczkowiczów było przekonanych co do zgłębiania tego zjawiska w momencie wypełniania kwestionariuszy, a tylko po cztery osoby $\mathrm{z}$ każdej $\mathrm{z}$ grup były przeciwnego zdania.

Uczestniczenie w festiwalu historycznym według grupy badanych jest dobrym sposobem na spędzanie wolnego czasu w trakcie letnich wyjazdów turystycznych. W pytaniu dotyczącym tej kwestii nie padła żadna negatywna odpowiedź, natomiast 99 osób spośród odwiedzających i uczestników było o tym zdecydowanie przekonane, 32 osoby były przekonane, a jedynie jedna osoba nie wiedziała, czy taka forma wypełniania wolnych chwil w pełni jej odpowiada.

O dużej atrakcyjności turystycznej XXI Festiwalu Słowian i Wikingów na Wolinie świadczy fakt, że w czasie przebywania na jego terenie $94 \%$ uczestników i 91\% odwiedzających było skłonnych do decyzji o przyjeździe na kolejną jego edycję za rok, a odpowiednio $95 \%$ oraz $100 \%$ obu tych grup było chętnych polecić znajomym i rodzinie kolejną edycję Festiwalu w roku 2016.

Wśród badanej grupy ujawniły się osoby będące zawodowo związane z turystyką lub historią. Aż 23 na 87 ankietowanych uczestników i 3 na 33 ankietowanych odwiedzających przyznało się do wykonywania pracy lub posiadania wykształcenia w zakresie wymienionych dziedzin. Do deklarowanych profesji należeli (w kolejności od najczęściej się pojawiających): archeolog, student turystyki i rekreacji, historyk, historyk sztuki, przewodnik, cieśla, jubiler, szkutnik, kowal, pracownik skansenu, budowniczy skansenów, konserwator zabytków, pilot wycieczek oraz hotelarz.

Obecność takich osób świadczy o pewnym przyciąganiu tematycznym będącym cechą Festiwalu, a jednocześnie sprawia, że ludzie zawodowo niepowiązani $z$ historią lub turystyką mogą zyskać od przedstawicieli wymienionych zawodów określoną wiedzę lub doświadczenie odnoszące się do tego wydarzenia.

XXI Festiwal Słowian i Wikingów był wydarzeniem rodzinnym i gromadzącym wielu znajomych. Jedynie siedmioro rekonstruktorów spośród 87 badanych zadeklarowało samodzielny przyjazd na im- prezę, a tylko pięcioro z 33 uczestników przyjechało samotnie. Większość badanych oznaczyła swój pobyt jako wyjazd $z$ rodziną lub znajomymi albo też $z$ rodziną i znajomymi. Na 80 rekonstruktorów w sumie przypadło 86 członków rodziny oraz 679 znajomych i drużynników. 28 odwiedzających przybyło w sumie z 43 osobami z rodziny oraz z 51 znajomymi. Taki wynik świadczy również o tym, że odtwórcy przybywali na Festiwal w znacznie liczniejszych grupach niż turyści i wycieczkowicze, gdyż na jednego uczestnika, który zadeklarował przybycie $\mathrm{w}$ grupie, przypadał 1,1 członek rodziny oraz 8,5 drużynników lub znajomych, natomiast statystycznie odwiedzający utrzymujący, że nie dotarł sam, spędzał czas w towarzystwie 1,5 członka rodziny i 1,8 znajomego.

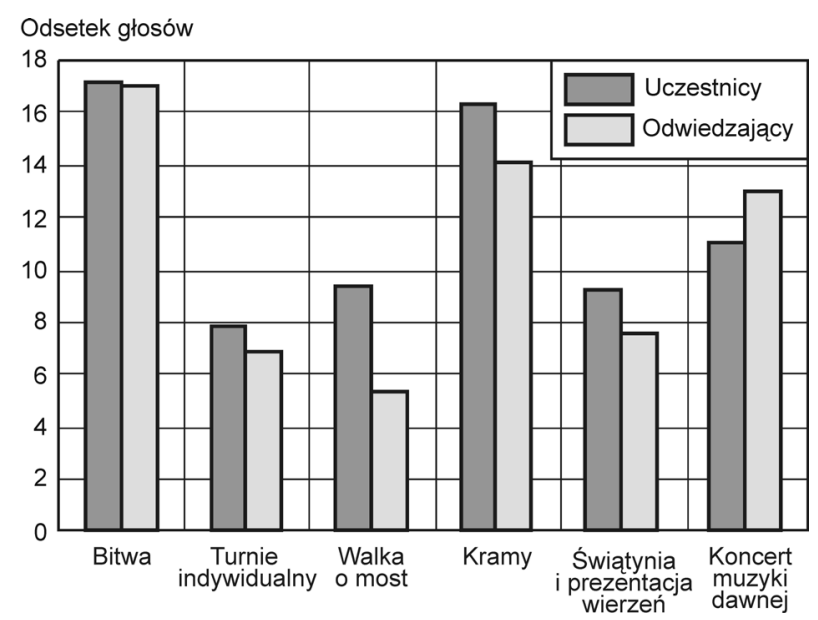

Rys. 5. Popularność poszczególnych atrakcji Festiwalu Słowian i Wikingów na Wolinie (cz. 1)

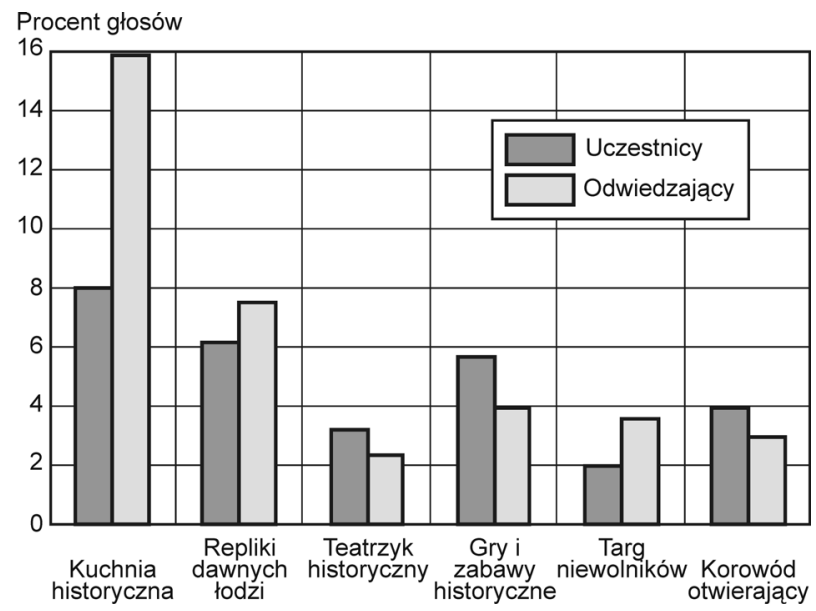

Rys. 6. Popularność poszczególnych atrakcji Festiwalu Słowian i Wikingów na Wolinie (cz. 2)

Ocenie podlegał również program Festiwalu. Autor wyszczególnił 12 atrakcji w kwestionariuszu ankiety, co pozwoliło na wykazanie różnic w popularności poszczególnych atrakcji wydarzenia wśród uczestników i odwiedzających (rys. 5 i 6). Spośród 12 
elementów wybierali pięć według nich najatrakcyjniejszych i na tej podstawie, w oparciu o wyliczenia procentowe, można było wyznaczyć punkty programu najmniej i najbardziej ciekawe.

Pierwsza część opracowania nie ujawnia dużej różnorodności wśród odpowiedzi. Najczęściej wybieraną atrakcją była bitwa, co nie jest zaskakujące ze względu na jej rozmach i efektowność. Zarówno turniej indywidualny, jak i kramy, świątynia oraz koncerty muzyki dawnej otrzymywały w obu grupach podobne noty. Sporą przewagę wśród uczestników w porównaniu do odwiedzających zyskała walka o most. Ma to swoje podłoże w być może zbyt dynamicznym charakterze tego typu starć. Obserwującemu z zewnątrz ciężko zorientować się co do aktualnego wyniku, natomiast dla rekonstruktorów rywalizacja w tej konkurencji stanowi formę prestiżu - tylko najlepsze 5-osobowe zespoły spośród każdej drużyny mogą wziąć w tym udział, a najlepsi z najlepszych wygrywają, przynosząc chwałę całej drużynie. Wynika stąd wysoka ocena wśród odtwórców, a relatywnie niska u odwiedzających.

Druga część wykresu dotyczącego popularności głównych atrakcji wydarzenia przynosi nieco większe różnice $\mathrm{w}$ ocenie między odwiedzającymi a uczestnikami. Dużo lepszy, bo dwukrotnie wyższy wynik osiągnęła kuchnia historyczna wśród grupy turystów i wycieczkowiczów. Przyczyną takiego stanu rzeczy może być fakt, że nie jest to dla nich codzienność, natomiast rekonstruktorzy są $\mathrm{z}$ tego typu jadłem zaznajomieni.

Odwiedzający ocenili wyżej niż odtwórcy repliki dawnych łodzi oraz targ niewolników, natomiast uczestnicy wyżej notowali teatrzyk historyczny, gry i zabawy historyczne oraz korowód otwierający Festiwal. Cechą wspólną takich wyników jest fakt, że dana grupa wyżej ocenia taki punkt programu, w którym może wziąć jak najbardziej aktywny udział. Odwiedzający niżej oceniali te punkty programu, w których byli jedynie obserwatorami.

Oceny głównych czynników mówiących o atrakcyjności miejsca odbywania się Festiwalu nie różniły się bardzo między badanymi uczestnikami a odwiedzającymi. 59\% pierwszej grupy i 55\% drugiej wskazało dziedzictwo kulturowe oraz historyczne Pomorza Zachodniego jako elementy o największym wpływie na wartość atrakcyjności lokalizacji Festiwalu. Drugie miejsce w obu grupach, zyskujące około $1 \frac{1}{3}$ głosów, zajęło położenie na wyspie. Pokazuje to różnice w rolach, jakie odgrywają w ocenie atrakcyjności turystycznej XXI Festiwalu Słowian i Wikingów walory antropogeniczne oraz przyrodnicze. Marginalny wpływ na to zagadnienie miała infrastruktura Wolina oraz inne elementy, natomiast bliska odległość do morza zyskała 6\% głosów zarówno wśród odwiedzających, jak i uczestników (rys. 7).

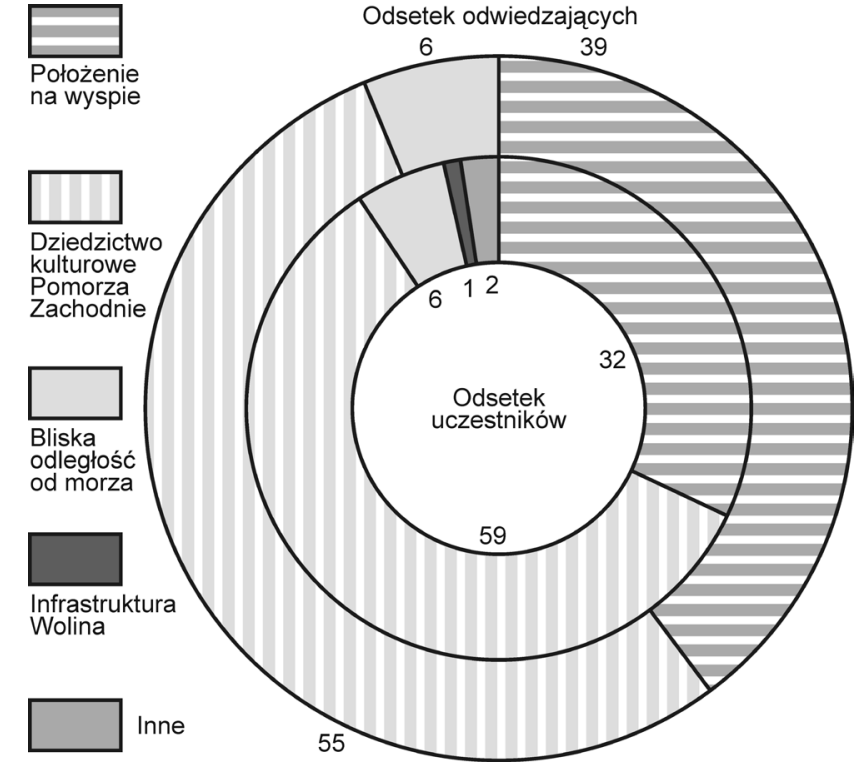

Rys. 7. Główne elementy decydujące o atrakcyjności miejsca Festiwalu Słowian i Wikingów na Wolinie

Badani zapytani zostali o wydarzenie ich zdaniem bardziej atrakcyjne na Pomorzu Zachodnim niż XXI Festiwal Słowian i Wikingów spośród dostępnych imprez konkurencyjnych. 100\% uczestników i 88\% odwiedzających nie potrafiło wskazać takiego wydarzenia. $12 \%$ odwiedzających wskazywało szczeciński pokaz sztucznych ogni "Pyromagic” odbywający się w sierpniu oraz małe uroczystości związane $\mathrm{z}$ ich miejscem zamieszkania (w przypadku osób pochodzących z Pomorza Zachodniego). Taki wynik obrazuje rolę, jaką odgrywa $\mathrm{w}$ turystyce Festiwal Słowian i Wikingów na Wolinie w skali całego regionu.

\section{PODSUMOWANIE}

XXI Festiwal Słowian i Wikingów na Wolinie można oceniać na wiele sposobów i z różnych perspektyw. Oczywiście, dostępność komunikacyjna, infrastruktura turystyczna oraz walory turystyczne (w przypadku Festiwalu - szczególny ich rodzaj, czyli walory krajoznawcze) stanowią o sile przyciągania odwiedzających jednodniowych i turystów, a także uczestników-odtwórców historycznych, jednakże przeciętny przedstawiciel żadnej ze wspomnianych grup prawdopodobnie nie rozpatrywał tego wydarzenia w kategoriach badawczych. Dla osoby takiej motywacją do spędzenia swojego czasu wolnego w ramach XXI edycji Festiwalu Słowian i Wikingów na Wolinie była swego rodzaju atmosfera, na którą złożyła się mnogość różnorodnych czynników, a potrzeba kwalifikacji któregokolwiek $z$ nich do zjawisk badanych przez turystykę raczej nie występowała. 
Atmosfera ta, przyciągając około 2000 rekonstruktorów z 27 krajów świata oraz ponad 30000 polskich i zagranicznych turystów oraz odwiedzających jednodniowych, co więcej - w większości przybywających po raz kolejny na Wolin - doskonale świadczy o autentyczności tezy wysoko sytuującej atrakcyjność turystyczną omawianej edycji Festiwalu.

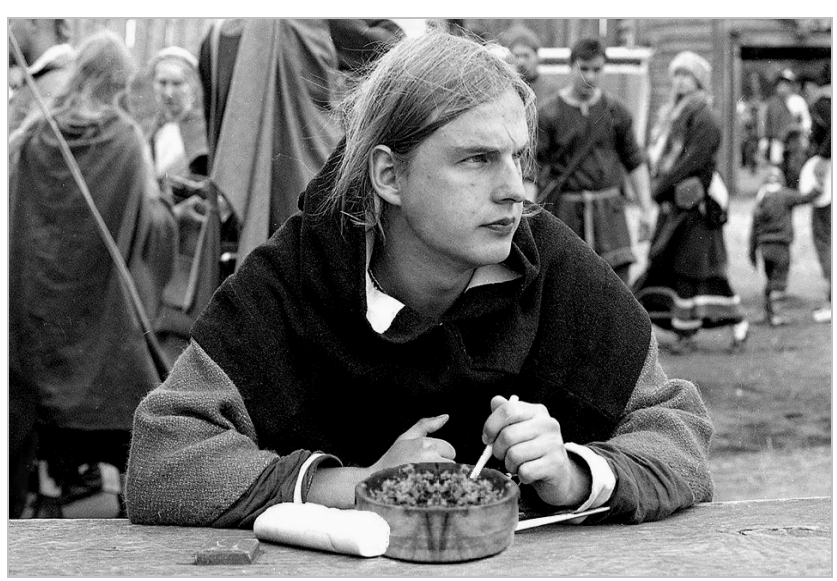

Fot. 6. Autor w czasie XXI Festiwalu Słowian i Wikingów na Wolinie Źródło: materiały autora

\section{PRZYPIS}

${ }^{1}$ Artykuł powstał na podstawie pracy licencjackiej pt. Atrakcyjność turystyczna XXI Festiwalu Stowian $i$ Wikingów, napisanej w Instytucie Geografii Miast i Turyzmu Uniwersytetu Łódzkiego pod kierunkiem dr Jolanty Latosińskiej.

\section{BIBLIOGRAFIA}

BOGACKI M., 2010, O wspótczesnym ożywianiu przesztości - charakterystyka odtwórstwa historycznego, [w:] Turystyka kulturowa, nr 5/2010, s. 4-27.

GÓREWICZ I.D., 2013, Mieczem pisane. Odtwórcologia, Triglav, Szczecin.

KOPALIŃSKI W., 2003, Stownik mitów i tradycji kultury, Oficyna Wydawnicza „Rytm”, Warszawa.

KOWALCZYK A., 2008, Wspótczesna turystyka kulturowa - między tradycją a nowoczesnościa, [w:] A. Kowalczyk (red.), Turystyka Kulturowa (spojrzenie geograficzne), Uniwersytet Warszawski, Warszawa, s. 13-14

LIJEWSKI T., MIKUŁOWSKI B., WYRZYKOWSKI J., 2008, Geografia turystyki Polski, Polskie Wydawnictwo Ekonomiczne, Warszawa.

MeCHŁo W., 2010, Pogańskie tajemnice Pomorza, Zapol, Szczecin. PAWLETA M., 2012, Rekonstrukcje i inscenizacje przesztości w perspektywie turystyki archeologicznej w Polsce, [w:] Skanseny archeologiczne $i$ archeologia eksperymentalna, Krosno, s. 364-380.

ROGALEWSKI O., 1979, Zagospodarowanie turystyczne, WSiP, Warszawa.

Ustawa z dnia 29 sierpnia 1997 r. o ustugach turystycznych, Dz.U. 1997, nr 133, poz. 884.

http:/ / www.jomsborg-vineta.com; 20.03.2016.

http://www. wolinpn.pl.

http://www.wsieciprawdy.pl/prod/news/large/festiwal_slo wian_i_wikingow_229.jpg; 5.01.2018. 